\title{
Revaluation as a Model of Subsequent Measurement of Property, Plant, and Equipment - Case of Croatia
}

\section{Mirjana Hladika}

Faculty of Economics and Business, University of Zagreb, Croatia mhladika@efzg.hr

\section{Danimir Gulin}

Faculty of Economics and Business, University of Zagreb, Croatia dgulin@efzg.hr

\section{Ivana Bernat}

Faculty of Economics and Business, University of Zagreb, Croatia ivalenta@efzg.hr

\author{
CroEconsur \\ Vol. 23 \\ No. 1 \\ June 2021 \\ pp. 63-95
}

Received: January 8, 2021

Accepted: April 14, 2021

Research Article

doi:10.15179/ces.23.1.3

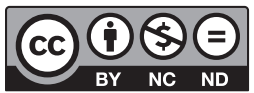

\section{Abstract}

Accounting standards allow the application of two models for subsequent measurement of property, plant, and equipment, and those are the cost model and the revaluation model. The application of a certain model depends on the manager's choice of accounting policy. The main goal of this paper is to investigate the application of the revaluation model for subsequent measurement of property, plant, and equipment in Croatian companies. Further goals are to examine how the fair value for revalued assets is determined, and what the level is of disclosed information about the determined fair value and the revaluation. The theoretical part of the paper analyzes different models for measurement of property, plant, and equipment, the issue of determining fair value, and disclosure requirements according to national and international accounting standards. The empirical part 
of the paper is conducted on 500 large and medium-sized Croatian companies from the service (utilities), production, and tourism sectors. Particular attention is placed on the notes to the financial statements of these companies. The research covers the period from 2014 to 2018. Collected data are analyzed by using descriptive statistics methods, point-biserial correlation, and Pearson correlation coefficient.

Keywords: revaluation; fair value; property, plant, and equipment; accounting standards; financial reporting

JEL classification: M40, M41

\section{Introduction}

The International Financial Reporting Standards (IFRS/IAS) are the most widely used set of accounting standards. They originated in the 1970s. According to EU Regulation 1606/2002, the consolidated financial statements of companies whose securities are traded on the financial market of any European Union member state should be prepared according to the IFRS (Regulation [EC] No. 1606/2002). The Croatian Financial Reporting Standards (CFRS) became effective on January 1, 2008 (Croatian Financial Reporting Standards, 2015). According to the Law on Accounting (Official Gazette, 2015), micro, small, and medium-sized entities prepare financial statements according to the CFRS.

IFRS and CFRS permit the use of the revaluation model and the cost model for subsequent measurement of property, plant, and equipment (PPE). The purpose of subsequent measurement of assets is to protect the integrity of assets, i.e., to prevent the transfer of assets through the distribution of income into consumption (see Gulin, 2021). According to the cost model, "the asset is evaluated on the purchase price of the asset and on all other costs directly attributable to bringing the asset to the condition capable for operating" (IASPlus, 2015, IAS 16.16). The main features of the cost model are certainty and simplicity, although there 
are many critics against this model. Critics argue that historical cost information is not relevant for users of financial statements because the historical price at the time of purchase can significantly differ from the market value of an asset and, accordingly, it helps conceal information about the financial health of a company, leading to market inefficiency (Bae, Lee, \& Kim, 2019). On the other hand, the fair value of an asset is usually determined as the market value of the asset, and this information can be more useful for different financial statement users. The fair value of property, plant, and equipment changes (either increases or decreases) due to utilization, technological development, passing of time, inflation, and other reasons. Therefore, the revaluation of property, plant, and equipment in order to update the carrying amount of these assets to the fair value is essential for the reliable presentation of property, plant, and equipment owned by a company (Bae et al., 2019; Sellhorn \& Stier, 2019). The fair value of property, plant, and equipment shows the current values of these assets and it improves the transparency, helps investors to predict future company performance, represents a better basis for investment decisions (Palea, 2014; Sellhorn \& Stier, 2019), and allows better informativeness of stakeholders and more efficient management (Ronen, 2008; Seng \& Su, 2011). However, the reliability of fair value information can be questionable if the active market for certain assets does not exist. Related to this, fair value measurement has been a controversial topic for years because in the absence of observable market prices an entity has to estimate a fair value that is very often a subject of manipulation (see Ball, 2006; Christensen \& Nikolaev, 2013). Financial statement users require transparent and reliable information about the financial position and business performance of a certain company in order to make appropriate business decisions. An active market for non-financial assets does not exist in Croatia, as in other developing countries, and that was the motive for conducting this research because PPE represents a significant share of total assets in many companies.

The goals of this paper are multiple. The first goal is to investigate if the companies in Croatia apply the revaluation model for subsequent measurement of PPE. 
Related to this, the second goal is to determine the frequency of revaluation of PPE in Croatia for those companies that apply the revaluation model for subsequent measurement of these assets. The third goal is to investigate which types of information companies disclose about the revalued PPE and determined fair value of these assets. The fourth goal is to explore which data companies use in order to determine the fair value of PPE.

This paper contributes to prior studies in some aspects. First, it provides incremental contributions to the literature in the field of applying the revaluation model in developing economies. Second, this study is focused on the application of the revaluation model in Croatian companies from the service (utilities), production, and tourism sectors and in doing so this research includes companies that apply IFRS and CFRS. This is the first research on the use of the revaluation model and related disclosures that includes companies that apply CFRS, while previous research that was conducted in Croatia included only listed companies that apply IFRS. Third, the volume of disclosed information about the determination of the fair value of property, plant, and equipment is based on the requirements of IAS 16 and IFRS 13 for companies that apply IFRS, and on the requirements of CFRS 6. The applied approach to the analysis of fair value disclosure requirements is different from the approach used in previous research. Furthermore, the pointbiserial correlation and Pearson correlation coefficient were not used as research methods in this field of accounting until now.

The paper is structured as follows. In the second section, we provide an overview of the models for measurement of PPE according to national and international accounting standards. Then we analyze the use of fair value as a measurement model for PPE with an emphasis on the inputs that are used in the fair value determination of these assets. We address fair value disclosures related to the determination of the fair value of PPE and the use of the revaluation model. The third section explains the research questions and applied research methodology. After the explanation of the research design, in the fourth section we present and discuss the research results. In the last part of the paper, we provide concluding remarks, point out the research limitations, and present future research directions. 


\section{Theoretical Background}

\subsection{Valuation of Property, Plant, and Equipment}

Accounting standards are a set of rules that determine the recognition criteria, as well as the initial and subsequent measurement of financial statement items. Rules for the initial recognition of an economic category define the requirements for measuring each item the first time it is presented in financial statements. Subsequent measurement means the valuation of each item of the financial statement after initial recognition. The valid rules for the measurement of PPE are provided in IAS 16 Property, plant, and equipment and CFRS 6 Long-term tangible assets (Table 1).

Table 1: Recognition and Measurement of Property, Plant, and Equipment According to IAS 16 and CFRS 6

\begin{tabular}{|c|c|c|}
\hline & IAS 16 & CFRS 6 \\
\hline Definition & $\begin{array}{l}\text { "Property, plant, and equipment are } \\
\text { tangible items that: (a) are held for use } \\
\text { in the production or supply of goods } \\
\text { or services, for rental to others, or for } \\
\text { administrative purposes; and (b) are } \\
\text { expected to be used during more than } \\
\text { one period." (IAS 16.6) }\end{array}$ & $\begin{array}{l}\text { "Long-term tangible assets that: (a) are } \\
\text { held for use in the production or supply } \\
\text { of goods or services, for rental to others, } \\
\text { or for administrative purposes; (b) are } \\
\text { expected to be used during more than } \\
\text { one period; and (c) are intended for use } \\
\text { on a continuous basis for the purpose of } \\
\text { the entity's activities." (CFRS 6.5) }\end{array}$ \\
\hline $\begin{array}{l}\text { Recognition } \\
\text { criteria }\end{array}$ & $\begin{array}{l}\text { "The cost of an item of property, plant, } \\
\text { and equipment shall be recognized as } \\
\text { an asset if, and only if: (a) it is probable } \\
\text { that future economic benefits associated } \\
\text { with the item will flow to the entity; and } \\
\text { (b) the cost of the item can be measured } \\
\text { reliably." (IAS 16.7) }\end{array}$ & $\begin{array}{l}\text { "The cost of an item of long-term } \\
\text { tangible assets shall be recognized as } \\
\text { an asset if, and only if: (a) it is probable } \\
\text { that future economic benefits associated } \\
\text { with the item will flow to the entity; and } \\
\text { (b) the cost of the item can be measured } \\
\text { reliably." (CFRS 6.19) }\end{array}$ \\
\hline $\begin{array}{l}\text { Initial } \\
\text { measurement }\end{array}$ & $\begin{array}{l}\text { "An item of property, plant, and } \\
\text { equipment that qualifies for recognition } \\
\text { as an asset shall be measured at its cost." } \\
\text { (IAS 16.15) }\end{array}$ & $\begin{array}{l}\text { "A long-term tangible asset that qualifies } \\
\text { for recognition as an asset shall be } \\
\text { measured at purchase cost." (CFRS 6.20) }\end{array}$ \\
\hline $\begin{array}{l}\text { Subsequent } \\
\text { measurement }\end{array}$ & $\begin{array}{l}\text { "An entity shall choose either the cost } \\
\text { model or the revaluation model as its } \\
\text { accounting policy and shall apply that } \\
\text { policy to an entire class of property, } \\
\text { plant, and equipment." (IAS 16.29) }\end{array}$ & $\begin{array}{l}\text { "An entity shall choose either the cost } \\
\text { model or the revaluation model as its } \\
\text { accounting policy and shall apply that } \\
\text { policy to an entire class of long-term } \\
\text { tangible assets." (CFRS } 6.30 \text { ) }\end{array}$ \\
\hline
\end{tabular}

Source: Systematized by the authors according to IAS 16 and CFRS 6. 
There are no significant differences in the rules for recognition, and initial and subsequent measurement of PPE between national (CFRS 6) and international standards (IAS 16). Minor differences are found only in the terminology and in the description of these rules. According to IAS 16 and CFRS 6, companies should measure PPE initially at its cost. Both standards (IAS 16 and CFRS 6) permit two accounting models for measurement of PPE subsequent to initial recognition, and those are the cost model and the revaluation model (Table 2).

Table 2: Comparison of Cost Model and Revaluation Model

\begin{tabular}{|c|c|}
\hline Cost model & Revaluation model \\
\hline \multirow{2}{*}{$\begin{array}{l}\text { "After recognition as an } \\
\text { asset, an item of property, } \\
\text { plant, and equipment shall } \\
\text { be carried at its cost less any } \\
\text { accumulated depreciation } \\
\text { and any accumulated } \\
\text { impairment losses." (IAS } \\
\text { 16.30; CFRS 6.31) }\end{array}$} & $\begin{array}{l}\text { "After recognition as an asset, an item of property, plant, and } \\
\text { equipment whose fair value can be measured reliably shall be } \\
\text { carried at a revalued amount, being its fair value at the date of } \\
\text { the revaluation less any subsequent accumulated depreciation and } \\
\text { subsequent accumulated impairment losses. }\end{array}$ \\
\hline & $\begin{array}{l}\text { Revaluations shall be made with sufficient regularity to ensure that } \\
\text { the carrying amount does not differ materially from that which } \\
\text { would be determined using fair value at the end of the reporting } \\
\text { period." (IAS 16.31; CFRS 6.32) }\end{array}$ \\
\hline
\end{tabular}

Source: Systematized by the authors according to IAS 16 and CFRS 6.

There are no differences between the cost model and revaluation model in IAS 16 and CFRS 6. Under the cost model, PPE is measured "at historical cost less accumulated depreciation and any accumulated impairment losses" (IAS 16.30; CFRS 6.31). Under the revaluation model, PPE is measured "at fair value at the date of revaluation less subsequent depreciation and any subsequent accumulated impairment losses" (IAS 16.31; CFRS 6.32). Both standards require that "revaluation has to be made often enough so that the carrying amount does not significantly differ from the fair value at the date of statement of financial position" (IAS 16.31; CFRS 6.32).

Under the revaluation model, the fair value of PPE is normally determined by appraisal. Both standards (IAS 16 and CFRS 6) require that when PPE is subsequently measured at revalued amounts, the entire class to which the asset belongs should be revalued. The aim of this requirement is to avoid the selective 
revaluation of certain PPE and to avoid reporting a mixture of historical costs and fair values for the same asset class in the financial statements (Herrmann, Saudagaran, \& Thomas, 2006).

Although the officially proclaimed purpose of the revaluation model is to present the real value (real picture) of property, plant, and equipment in the statement of financial position, previous research has identified various hidden motives for applying this model. Aboody, Barth, and Kasznik (1999) found that revaluation has a positive impact on the company's future performance influenced by income and operating cash inflows. Cheng and Lin (2009) confirmed that motives for applying the revaluation model are reducing the information asymmetry problems among stakeholders, reducing debt contracting costs, and reducing high political costs. Missonier-Piera (2007) found that leverage, investment opportunities, and foreign sales are associated with the use of the revaluation model for subsequent measurement of fixed assets, and that the application of this model presents a vehicle towards improving the perceptions of international stakeholders and borrowers about the financial health of the company. Chainirun and Narktabtee (2009) identified company's future performance, company's liquidity, and growth opportunities as motives behind the application of the revaluation model. Aljinović Barać and Šodan (2011, p. 61) highlighted that "managers reduce the company's perceived risk to the creditors and improve the company's financial position and consequently reduce debt cost" by using the revaluation model. They conducted a research on Croatian listed companies (2000-2008) and found that large and profitable companies with low cash flow ratio, low liquidity ratio, and increasing debt are more likely to apply the revaluation model for subsequent measurement of property, plant, and equipment. Choi, Pae, Park, and Song (2013) found that the revaluation model contributes to the increase of a company's borrowing capacity and improves its financial position. Lopes and Walker (2012) pointed out the improvement of a company's equity position as a motive for applying the revaluation model. Hu, Percy, and Yao (2015) highlighted that the revaluation of fixed assets has a positive impact on management earnings. Rahman and Hossain 
(2020) pointed out that the revaluation model has a significant impact on the financial numbers and financial indicators of a company, such as the net asset value, fixed asset value, and debt-to-equity ratio.

\subsection{Fair Value as a Measurement Model}

The practice and theory of accounting distinguish two basic models for the measurement of economic categories - historical cost model and fair value model. The historical cost model is the oldest measurement model, while the fair value model was officially introduced by the International Accounting Standards Board in the mid-1970s in order to use it as an alternative measure to the historical cost model. The historical cost model requires the recording of an asset at the value (amount) at which it was purchased, while the fair value model requires the updating of the value of assets on a regular basis (Greenberg, Helland, Clancy, \& Dertouzos, 2013).

The fair value model today is used as a model for measurement of different types of assets and liabilities, either as a mandatory or as an alternative model. Fair value is thus mentioned in over 20 of the IAS and IFRS standards today. For many years, the guidance on fair value determination and related disclosures was distributed among several IAS and IFRS standards, and they contained quite limited guidance and requirements and were often inconsistent. In order to provide a detailed and unified guidance on the measurement of fair value of all types of economic categories and harmonized requirements for disclosures on fair value for the purpose of financial reporting, in 2011 the International Accounting Standards Board introduced IFRS 13 Fair value measurement (with application from January 1, 2013).

Fair value, under IFRS 13, is defined as "the price that would be received to sell an asset or paid to transfer a liability in an orderly transaction between market participants at the measurement date" (IASPlus, 2013, IFRS 13.9) (i.e., an exit price). The definition emphasizes that "fair value is a market-based value rather 
than an entity-specific value" (IFRS 13.2). In determining the fair value of a certain item, "a business entity applies the assumptions that market participants would apply in order to determine the price of the asset or liability under certain market conditions, including assumptions about risk" (IFRS 13.3).

The measurement of financial statement items is a key factor in preparing financial statements that fairly and reliably show the results of economic activities of an entity as well as its financial position and business performance (Procházka, 2011). If an entity uses the fair value model for the measurement of a certain type of asset or liability, users of the financial statements are interested in the information that is used to determine the fair value and in the costs of fair value determination.

In order to increase the comparability and consistency of determined fair value measures and related disclosures, IFRS 13 Fair value measurement establishes the "fair value hierarchy that categorizes the inputs to valuation techniques used to measure fair value into three levels - level 1, level 2, and level 3" (IFRS 13.72) (Table 3).

The highest priority in determining the fair value is given to quoted prices (unadjusted) in active markets for identical assets or liabilities (level 1 inputs), while the lowest priority is given to unobservable inputs (level 3 inputs). The best indicator of fair value is the current market price for identical assets, in identical locations and conditions, and under identical contract requirements. Therefore, quoted prices in active markets have to be used whenever they are available, and their usefulness for financial statements users is the highest information asymmetry between managers and financial statement users is very low (Majercakova \& Skoda, 2015). 
Table 3: Fair Value Hierarchy and Valuation Techniques According to IFRS 13 Fair Value Measurement

\begin{tabular}{c|l|l}
\hline Level & \multicolumn{1}{|c}{ Input } & Valuation techniques \\
\hline Level 1 & $\begin{array}{l}\text { "Quoted prices for identical assets or liabilities in active markets" } \\
\text { (IFRS 13.76) } \\
\text { "Quoted prices for similar assets or liabilities in active markets; } \\
\text { Level 2 }\end{array}$ & $\begin{array}{l}\text { quoted prices for identical or similar assets or liabilities in } \\
\text { markets that are not active; } \\
\text { interest rates and yield curves observable at commonly quoted } \\
\text { intervals, implied volatilities, credit spreads; } \\
\text { inputs that are derived principally from or corroborated by } \\
\text { observable market data by correlation or other means" (IFRS } \\
13.82)\end{array}$ \\
\hline Level 3 & "Unobservable inputs for the asset or liability" (IFRS 13.86) & Market approach \\
\hline
\end{tabular}

Source: Systematized by the authors according to IFRS 13 Fair value measurement.

If the market for a certain asset is neither active nor liquid, the most important question is which inputs are available to estimate the fair value of that asset. In those circumstances, fair value estimates are based on level 2 or level 3 inputs. "Level 2 and level 3 inputs have to be used in order to determine fair value if observable inputs are not disposable, which is commonly referred to as the mark-to-model approach" (Gulin \& Hladika, 2016, p. 3). Song, Thomas, and $\mathrm{Yi}$ (2010) find that fair value that is determined based on level 1 inputs are more value-relevant than fair value determined based on level 2 and level 3 inputs, while fair values determined based on level 3 inputs are far less reliable than fair values determined based on level 1 and level 2 inputs. In line with these results are also the results of studies conducted by Fargher and Zhang (2014), Gulin, Hladika, and Mićin (2017), McDonough, Panaretou, and Shakespeare (2020), and Zyla (2013).

There are many previous research studies about applying fair value as a measurement base for financial assets (see Beatty \& Liao, 2014; Laux, 2012; Yao, Percy, Stewart, \& Hu, 2018) and non-financial assets. Although previous research showed that companies apply the fair value and revaluation models for subsequent 
measurement of non-financial assets, their use is still very rare in practice. Some of the reasons for this are listed below. First of all, implementation of the fair value model as a measurement model requires certain very specific conditions, such as developed and active markets. In many countries, only a liquid financial market is established, but not a market for non-financial assets. Consequently, the determination of fair value for non-financial assets relies on observable inputs rather than on quoted market prices, or on unobservable inputs, which leads to the use of a high level of subjective assessment and increases the risk of manipulation. Furthermore, the nature of financial assets and non-financial assets differ, as does their role in doing daily business. Finally, a financial asset is primarily linked to the financial industry, which is subject to specific regulatory requirements depending on the business, and financial reporting.

As mentioned, previous studies document a modest use of fair value measurement (i.e., applying the revaluation model) for PPE. Cheng and Lin (2009) investigated the use of the revaluation model for fixed assets in UK companies in the period from 1994 to 1998 and they found that 8.38 percent (563) companies from the sample revalued their assets during the observed period. Šodan (2009) analyzed the use of the fair value model for the measurement of property, plant, and equipment (IAS 16), intangible assets (IAS 38), and investment property (IAS 40) on a sample of 180 Croatian companies listed on the Zagreb Stock Exchange. The results showed that the use of the fair value model is rare in the observed companies. Aljinović Barać and Šodan (2011) examined the use of the revaluation model for subsequent measurement of property, plant, and equipment on a sample of Croatian companies listed on the Zagreb Stock Exchange in the period from 2000 to 2008 . The results of their study showed that only 9 percent (224) of the companies in the sample apply the revaluation model. Cairns, Massoudi, Taplin, and Tarca (2011) investigated the use of fair value for measurement of PPE by listed companies in the UK (114 companies) and Australia (114 companies). They found that only 2 percent of the UK companies and 7 percent of the Australian companies apply the revaluation model for subsequent measurement of property, 
while none of the companies in the sample apply the revaluation model for subsequent measurement of plant and equipment. Christensen and Nikolaev (2013) examined the use of the revaluation model for subsequent measurement of PPE by 934 UK companies and 605 German companies that apply IFRS. The results of their research showed that the fair value measurement of PPE and the use of the revaluation model are very rare - only 6.6 percent of the UK companies and 1.16 percent of the German companies apply the revaluation model. In doing so, the majority of them apply the revaluation model for subsequent measurement of property, as opposed to its application for subsequent measurement of plant and equipment. In line with these results, Nobes and Stadler (2013) investigated 514 large listed companies from 12 countries that apply IFRS and found that the use of the fair value and revaluation model for subsequent measurement of PPE is very rare. They found that a very small percentage of companies in the research sample use the revaluation model for subsequent measurement of property - only 10 percent of Australian companies, 10 percent of Canadian companies, 5 percent of Hong Kong companies, and 10 percent of UK companies, whereas none of the companies from other countries (China, France, Germany, Italy, South Africa, South Korea, Spain, and Switzerland) apply the revaluation model.

\subsection{Disclosure Requirements Related to Determination of Fair Value and the Application of the Revaluation Model}

Detailed descriptions and clarifications of items of financial statements should be presented in the notes to the financial statements. For financial statement users to gain a comprehensive and complete picture about the company's financial position and business performance, an entity should present additional information (qualitative and quantitative) in the notes to the financial statements. Disclosure requirements for particular items of the financial statement are defined in each accounting standard. If we consider IFRS, the disclosure requirements are quite extensive. Each entity individually decides which information it will disclose in the notes to the financial statements and in which form. 
Disclosure requirements related to fair value determination and the application of the revaluation model for subsequent measurement of PPE are presented in Table 4.

Table 4: Disclosures Related to Fair Value Determination and the Application of the Revaluation Model

\begin{tabular}{|c|c|c|}
\hline IFRS 13 & IAS 16 & CFRS 6 \\
\hline $\begin{array}{l}\text { "IFRS } 13 \text { requires an entity to } \\
\text { disclose information that helps } \\
\text { users of its financial statements } \\
\text { assess both of the following: (a) } \\
\text { for assets and liabilities that are } \\
\text { measured at fair value on a recurring } \\
\text { or non-recurring basis in the } \\
\text { statement of financial position after } \\
\text { initial recognition, the valuation } \\
\text { techniques and inputs used to } \\
\text { develop those measurements; and } \\
\text { (b) for fair value measurements } \\
\text { using significant unobservable } \\
\text { inputs (level } 3 \text { inputs), the effect of } \\
\text { the measurements on profit or loss or } \\
\text { other comprehensive income for the } \\
\text { period" (IFRS } 13.91 \text { ) }\end{array}$ & $\begin{array}{l}\text { "If items of property, plant, and } \\
\text { equipment are stated at revalued } \\
\text { amounts, the following shall be } \\
\text { disclosed: (a) the effective date } \\
\text { of the revaluation; (b) whether } \\
\text { an independent valuer was } \\
\text { involved; (c) for each revalued } \\
\text { class of property, plant, and } \\
\text { equipment, the carrying } \\
\text { amount that would have been } \\
\text { recognized had the assets been } \\
\text { carried under the cost model; } \\
\text { and (d) the revaluation surplus, } \\
\text { indicating the change for the } \\
\text { period and any restrictions on } \\
\text { the distribution of the balance } \\
\text { to shareholders" (IAS 16.77) }\end{array}$ & $\begin{array}{l}\text { "In the case when the } \\
\text { long-term tangible assets } \\
\text { are measured at revalued } \\
\text { amounts, the following } \\
\text { shall be disclosed: increases } \\
\text { or decreases resulting } \\
\text { from the revaluation in } \\
\text { the reporting period with } \\
\text { an explanation of the tax } \\
\text { treatment of contained } \\
\text { items, including increases, } \\
\text { decreases, and transfers } \\
\text { resulting from revaluation, } \\
\text { and impairment losses on } \\
\text { revalued assets recognized } \\
\text { or abolished directly in } \\
\text { equity" (CFRS 6.70) }\end{array}$ \\
\hline
\end{tabular}

Source: Systematized by the authors according to IFRS 13, IAS 16, and CFRS 6.

Disclosure requirements related to fair value determination are specified in the international standard (IFRS 13), while a national standard (CFRS) that deals with fair value still does not exist. Disclosure requirements relating to the application of the revaluation model for subsequent measurement of PPE have certain specifics in national and international standards.

Companies are required to make comprehensive disclosures related to fair value measurements recognized in their financial statements. The disclosures about items recognized at fair value differ depending on whether the items are measured on a recurring or non-recurring basis. In many cases, the fair value is a result of an estimate that is based on level 2 or level 3 inputs, so the disclosure related to fair value determination is important for financial statement users for the purpose of making business decisions. These disclosures can help them to better ascertain 
the extent to which fair value was measured with a high or low degree of certainty (McDonough et al., 2020). Gaynor, McDaniel, and Yohn (2011) point out that the usefulness of fair value information is often conditioned on the understanding of disclosed information by financial statement users.

The disclosure of information related to applying the revaluation model for subsequent measurement of PPE is poor and depends on the quality, verifiability, and reliability of the fair value measures. Missonier-Piera (2007) stressed that the choice of accounting policy is systematically related to company-specific characteristics, which means that a certain company optimizes the amount and type of information provided to external users of financial statements by weighing the related costs and benefits for the company. Similar motives for nondisclosure of certain information are identified in a study conducted by Bae et al. (2019). Song and Pae (2019) highlighted that an increase in the value of fixed assets through revaluation contributes to high information asymmetry about the property, plant, and equipment, and that is the reason why such information is not disclosed.

Many previous studies analyzed the factors that influence the volume of disclosed information about PPE. Oliveira, Rodrigues, and Craig (2006) and Lopes and Rodrigues (2007) found a statistically significant positive correlation between the company's size and the number of disclosures on PPE. Namely, larger companies disclose more information in comparison with medium and small-sized companies. On the other hand, Gastón, García, Jarne, and Gadea (2010) and Botelho, Azevedo, Costa, and Oliveira (2015) found no association between the company's size and the number of disclosures. Aljifri (2008), Morais and Fialho (2008), and Oliveira et al. (2006) found that there is no or very low association between the company's profitability and the number of disclosures in the notes to the financial statements.

International standards require the disclosure of information on whether an independent (external) appraiser was involved in the assessment of the fair value of PPE. Cotter and Richardson (2002) found that companies are less likely to 
involve an external appraiser for plant and equipment (as opposed to property) and attribute this finding to internal appraisers' specific knowledge about the use of these assets. Müller, Riedl, and Sellhorn (2015) highlighted that companies holding an asset for which fair value estimates can be determined less reliably are more likely to engage an external appraiser.

\section{Research Questions and Methodology}

The main goal of this paper is to investigate whether Croatian companies apply the revaluation model for subsequent measurement of property, plant, and equipment and whether the companies fulfill the disclosure requirements defined in the accounting standards. In order to achieve this goal, we address the following research questions:

RQ1: Do companies in Croatia apply the revaluation model for subsequent measurement of PPE?

RQ2: How often is revaluation carried out in companies that apply the revaluation model for subsequent measurement of PPE?

RQ3: Does the value of fixed assets determine frequency of revaluation?

RQ4: Do companies fulfill all the requirements of the standards regarding the disclosure of revaluation and fair value information?

RQ5: What inputs are used to determine fair value in subsequent measurement of PPE?

In order to fulfill the research goals and to answer the research questions, we designed the sample selection process. In doing so, we decided to focus our research on the companies from the service (utilities), production, and tourism sectors. These sectors were chosen because the results of previous research conducted by Gulin, Hladika, and Bernat (2019) and Perčević, Hladika, and Valenta (2020) 
have shown that the revaluation model in Croatia is mostly used by companies from these sectors. The data for conducting the research were gathered from publicly available financial statements of large and medium-sized companies from the service (utilities), production, and tourism sectors that have submitted their financial statements in the Register of Annual Financial Statements kept by the Financial Agency. The research covers a five-year period, from 2014 to 2018. We analyze only those companies that have submitted their financial statements for all five years - 2014, 2015, 2016, 2017, and 2018. We selected the first 500 large and medium-sized companies from the service (utilities), production, and tourism sectors ranked by asset value.

Considering the fact that in Croatia there is no single database that could indicate which companies use the revaluation model, we used convenience sampling. We analyzed notes to the financial statements and accounting policies of all 500 companies for each of the five years that state whether the company applies the revaluation model for subsequent measurement of PPE. Using hand-collected data, we filtered 44 companies (8.8 percent) that apply the revaluation model for subsequent measurement of PPE.

Further analysis is based on the research sample, which consists of 44 companies that apply the revaluation model for subsequent measurement of PPE. The structure of companies included in the sample by business sector is shown in Table 5.

Table 5: Sample Structure by Business Sector

\begin{tabular}{l|c|c}
\hline Business sector & Number & Percentage \\
\hline Production & 13 & $30 \%$ \\
\hdashline Service & 22 & $50 \%$ \\
Tourism & 9 & $40 \%$ \\
Total & 44 & $\mathbf{1 0 0} \%$ \\
\hline
\end{tabular}

Source: Authors' calculations. 
Most companies in the research sample belong to the service sector (utilities). This can be explained by the fact that these companies have the largest proportion and value of property, plant, and equipment in total assets compared to companies from other business sectors, and that companies from the service sector (utilities) apply the revaluation model the most often.

Collected data are analyzed by using methods of descriptive statistics, pointbiserial correlation, and Pearson correlation coefficient.

\section{Research Results and Discussion}

\subsection{Application of the Revaluation Model}

The empirical research consists of an in-depth analysis of the notes to the financial statements of 44 companies that apply the revaluation model for subsequent measurement of PPE. The research results show that 75 percent of the companies in the research sample apply the revaluation model for subsequent measurement of land (land is analyzed separately because it represents an item of property that is not subject to depreciation), 55 percent of the companies apply the revaluation model for subsequent measurement of property, plant, and equipment, and 27 percent of the companies apply the revaluation model for subsequent measurement of both types of assets (land and property, plant, and equipment) (see Table 6).

Table 6: Type of Revalued Asset

\begin{tabular}{l|c|c}
\hline Category of asset & Number & Percentage \\
\hline Land & 33 & $75 \%$ \\
\hline Property, plant, and equipment & 24 & $55 \%$ \\
Land, property, plant, and equipment & 12 & $27 \%$ \\
\hline
\end{tabular}

Source: Authors' calculations.

In the next step of the research, the frequency of conducting a revaluation is analyzed. Thus, we analyzed how many companies conducted a fair value 
assessment of their land, property, plant, and equipment in a certain year. In order to achieve this goal, we analyzed notes to the financial statements for the five-year period from 2014 to 2018. The results of this analysis are shown in Table 7.

Table 7: Frequency of Conducting a Revaluation

\begin{tabular}{l|l|l|l|l|l}
\hline Year & $\mathbf{2 0 1 8}$ & $\mathbf{2 0 1 7}$ & $\mathbf{2 0 1 6}$ & $\mathbf{2 0 1 5}$ & $\mathbf{2 0 1 4}$ \\
\hline $\begin{array}{l}\text { \% of companies that } \\
\text { conducted a revaluation }\end{array}$ & $33.2 \%$ & $10.0 \%$ & $13.5 \%$ & $10.0 \%$ & $23.4 \%$ \\
\hline
\end{tabular}

Source: Authors' calculations.

A total of 220 notes to the financial statements were analyzed, and the results show that most of the companies in the research sample conducted a revaluation in 2018. The reason why most companies conducted a revaluation in 2018 should be analyzed from the standpoint of the situation in the real estate market in Croatia. In data analysis, we used average house prices because only they are publicly available, and they clearly show the trend that can be transferred to the price of commercial land and property. Table 8 shows the annual average house price indices in Croatia published by the Croatian Bureau of Statistics.

Table 8: Annual Average House Price Indices in Croatia

\begin{tabular}{|c|c|c|}
\hline \multirow[t]{2}{*}{ Year } & $\begin{array}{c}\text { Annual average indices } \\
(\emptyset 2015=100)\end{array}$ & $\begin{array}{c}\text { Annual average rates of change, } \% \\
(\text { previous year }=100)\end{array}$ \\
\hline & Total & Total \\
\hline 2014 & 102.98 & -1.6 \\
\hline 2015 & 100.00 & -2.9 \\
\hline 2016 & 100.89 & 0.9 \\
\hline 2017 & 104.75 & 3.8 \\
\hline 2018 & 111.14 & 6.1 \\
\hline
\end{tabular}

Source: Croatian Bureau of Statistics (2020).

As can be seen in Table 8, in 2018 the annual average house price rate of change was 6.1 percent, which is the largest increase in the observed period. If we look at 
annual average indices, it can be concluded that in 2018 house prices were at the highest level in the observed period.

With the aim of better understanding the relationship between these variables, Figure 1 shows the fluctuation of house price indices and the percentage of companies that applied the revaluation model in the period from 2014 to 2018 .

Figure 1: Fluctuation of House Price Indices and Application of the Revaluation Model

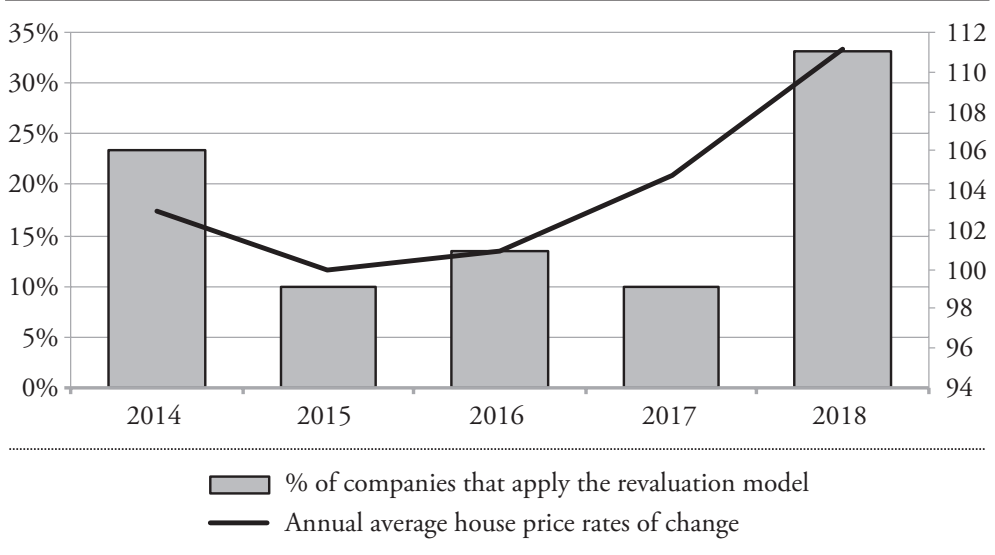

Source: Authors' calculations.

Figure 1 compares the share of companies that apply the revaluation model and annual average house price rates of change. We can conclude that there is a positive correlation between these two variables. In 2015, annual average house price rates of change dropped, as did the share of companies that apply the revaluation model, while 2018 saw a significant rise in house prices and the share of companies that apply the revaluation model.

Analysis of the frequency of revaluation of property, plant, and equipment shows that companies in the research sample most often conducted a revaluation two times in the observed period. Further analysis shows that most companies 
conducted a revaluation in 2014 and 2018, which leads us to the conclusion that in average they revaluate their property, plant, and equipment every five years.

The third research question refers to the connection between the frequency of revaluation and the value of fixed assets. The goal is to determine whether the value of fixed assets has an impact on the frequency of their revaluation. For this purpose, we used point-biserial correlation, which measures the strength and direction of the association that exists between one continuous variable and one dichotomous variable. Table 9 shows the results of analysis in SPSS.

Table 9: Point-Biserial Correlation Between Frequency of Revaluation and Value of Fixed Assets

\begin{tabular}{|c|c|c|c|}
\hline \multicolumn{4}{|l|}{ Correlations } \\
\hline & & $\begin{array}{l}\text { Frequency of } \\
\text { revaluation }\end{array}$ & Value of fixed assets \\
\hline \multirow[t]{3}{*}{$\begin{array}{l}\text { Frequency of } \\
\text { revaluation }\end{array}$} & $\begin{array}{l}\text { Point-biserial } \\
\text { correlation }\end{array}$ & 1 & 0.351 \\
\hline & Sig. (2-tailed) & & 0.001 \\
\hline & $N$ & 220 & 220 \\
\hline \multirow[t]{3}{*}{ Value of fixed assets } & $\begin{array}{c}\text { Point-biserial } \\
\text { correlation }\end{array}$ & 0.351 & 1 \\
\hline & Sig. (2-tailed) & 0.001 & \\
\hline & $N$ & 220 & 220 \\
\hline
\end{tabular}

Source: Authors' calculations in SPSS.

In order to conduct a point-biserial correlation, the value of fixed assets for the companies in our sample was collected. A point-biserial correlation was run to determine the relationship between the value of fixed assets and the frequency of revaluation. The results show that there is a positive linear relationship between the value of fixed assets and the frequency of revaluation, but this relationship is not statistically significant. 


\subsection{Disclosure of Information Related to Revaluation of Property, Plant, and Equipment}

Companies in Croatia apply International Financial Reporting Standards (IFRS/ IAS) and Croatian Financial Reporting Standards (CFRS) for the preparation of financial statements. According to the Law on Accounting (Official Gazette, 2015), micro, small, and medium-sized companies in Croatia are required to apply CFRS, while large companies and those whose stock or debt securities are listed or are prepared for listing on the stock exchange, have to apply IFRS. For companies that apply IFRS, two standards are relevant for measurement and disclosures on PPE and fair value: IAS 16 and IFRS 13. For companies that apply CFRS, the relevant standard is CFRS 6. In comparison with CFRS, the IFRS standards require much more detailed disclosure of information about the revaluation and the fair value calculation.

In the research sample, which consists of 44 companies, 25 companies apply IFRS and 19 companies apply CFRS. The companies are classified in different categories depending on the type and volume of disclosed information about the revaluation and fair value determination in the notes to the financial statements. Accordingly, based on the type and volume of disclosed information about the revaluation and fair value determination in comparison with information that is required to be disclosed according to IFRS, the companies are classified in three categories (Table 10).

Table 10: Disclosure of Required Information About the Revaluation and Fair Value Determination According to IFRS

\begin{tabular}{c|l|c}
\hline Category & \multicolumn{1}{|c}{ Disclosed information } & Companies \\
\hline Category 1 & $\begin{array}{l}\text { Companies that fulfill all disclosure requirements for revalued } \\
\text { property, plant, and equipment (IAS 16.77 Disclosure) and fair value } \\
\text { (IFRS 13.91 Disclosure) }\end{array}$ & $20 \%$ \\
\hline Category 2 & $\begin{array}{l}\text { Companies that fulfill disclosure requirements only for revalued } \\
\text { property, plant, and equipment (IAS 16.77 Disclosure), but do not } \\
\text { fulfill disclosure requirements about fair value (IFRS 13.91 Disclosure) }\end{array}$ & $32 \%$ \\
\hline Category 3 3 & $\begin{array}{l}\text { Companies that do not fulfill the requirements of the standards and do } \\
\text { not disclose any information on revaluation and fair value }\end{array}$ & $48 \%$ \\
\hline
\end{tabular}

Source: Authors' elaboration based on notes to the financial statements and requirements of IAS 16.77 and IFRS 13.91 . 
According to IAS 16, for PPE that is subsequently measured at revalued amounts, apart from basic information, companies need to disclose some additional information such as: "the effective date of revaluation; whether an independent appraiser was involved for each revalued class of property, plant, and equipment; the carrying amount that would have been recognized had the assets been carried under the cost model; the revaluation surplus, including changes during the period and any restrictions on the distribution of the balance to shareholders" (IAS 16.77). IFRS 13 also requires the disclosure of certain additional information about the revalued asset: "for assets and liabilities that are measured at fair value on a recurring or non-recurring basis in the statement of financial position after initial recognition, the valuation techniques and inputs used to develop those measurements, and for fair value measurements using significant unobservable inputs (level 3), the effect of the measurements on profit or loss or other comprehensive income for the period" (IFRS 13.91).

Analysis of the notes to the financial statements shows that most companies in the research sample have published poor-quality notes that do not contain all the information required by the standards. Almost 50 percent of companies in the research sample are classified in the third category, which means that information about the revalued assets was not disclosed in the notes to the financial statements. In-depth analysis of these notes to the financial statements shows that companies disclose a low level of information, and that the notes to the financial statements are very short, without basic information and with a lot of mistakes and corrections that make it difficult to track changes. Around 32 percent of notes to the financial statements of the companies in the research sample contain information that is required by IAS 16, and these companies are classified in the second category. In-depth analysis shows that most companies that are classified in the second category disclose only basic information (the basis for measuring the carrying amount, the depreciation method used, useful lives or depreciation rates, increases and decreases of revaluation, impairment losses). Only 20 percent of companies in the research sample are classified in the first category. This means 
that the notes to the financial statements of these companies contain information that is required by IAS 16 and IFRS 13, which makes up a full set of information.

In the next step, the research included the analysis of notes to the financial statements of companies that apply Croatian Financial Reporting Standards. The results of this analysis are presented in Table 11.

Table 11: Disclosure of Required Information About the Revaluation and Fair Value Determination According to CFRS

\begin{tabular}{c|l|c}
\hline Category & \multicolumn{1}{|c}{ Disclosed information } & Companies \\
\hline \multirow{2}{*}{ Category 1 } & $\begin{array}{l}\text { Companies that fulfill all disclosure requirements for revalued } \\
\text { property, plant, and equipment (CFRS 6.70 Disclosure) }\end{array}$ & $26 \%$ \\
Category 2 & $\begin{array}{l}\text { Companies that do not fulfill the requirements of the standard and do } \\
\text { not disclose any information on revaluation and fair value }\end{array}$ & $74 \%$ \\
\hline
\end{tabular}

Source: Authors' elaboration based on notes to the financial statements and requirements of CFRS 6.70.

CFRS 6 requires the disclosure of the following information for the property, plant, and equipment being subsequently measured at revalued amounts: increases or decreases resulting from the revaluation in the reporting period with an explanation of the tax treatment of contained items, including increases, decreases, and transfers resulting from revaluation, and impairment losses on revalued assets recognized or abolished directly in equity.

As shown in Table 11, 26 percent of companies that apply CFRS are classified in the first category, which means that the notes to the financial statements of these companies are prepared in accordance with CFRS 6 requirements. Analysis shows that although there are less disclosure requirements for companies that apply CFRS than for companies that apply IFRS, only a small proportion of companies publish all the required information. 74 percent of companies from the research sample that apply CFRS do not disclose any information about the revalued asset. In-depth analysis shows that more than 20 percent of companies in the research sample that apply CFRS do not disclose any information about their property, plant, and equipment, or they disclose just a small amount of such 
information in the notes to the financial statements. The reasons for this can be found in the fact that neither CFRS nor the Croatian Law on Accounting require the publication of such information, as well as in the lower quality of the financial statements and reduced control of audit firms.

In order to investigate if the size of the company (independent variable) and the profitability of the company (independent variable) have a certain impact on the level of disclosed information in the notes to the financial statements (dependent variable), we calculate the Pearson correlation coefficient (Table 12).

Table 12: Pearson Correlation Coefficient

\begin{tabular}{l|c|c|cc} 
& Companies that apply IFRS & Companies that apply CFRS \\
& Correlation & P-value & Correlation & P-value \\
\hline $\begin{array}{l}\text { The level of disclosed information } \\
\text { and the size of the company }\end{array}$ & 0.2972 & 0.1781 & 0.2426 & 0.3250 \\
\hline $\begin{array}{l}\text { The level of disclosed information } \\
\text { and the profitability of the company }\end{array}$ & 0.2413 & 0.6594 & 0.1937 & 0.2687 \\
\hline
\end{tabular}

Source: Authors' calculations.

According to the Pearson correlation coefficient, which evaluates the linear relationship between the variables, we can conclude that the relationship is positive between the level of disclosed information and the size of the company as well as between the level of disclosed information and the profitability of the company, but in both cases the relationship between the observed variables is not statistically significant $(\mathrm{p}>0.05)$.

\subsection{Fair Value of Revalued Property, Plant, and Equipment}

Considering the fact that a small number of companies from the research sample have disclosed all the required information on how they determine the fair value of PPE that is subsequently measured at revalued amounts, below is a qualitative analysis of the published information. 
All companies in the research sample that disclose information required by IFRS 13 use level 2 inputs in the valuation of the fair value of their assets. "Level 2 inputs include quoted prices for similar assets or liabilities in active markets or quoted prices for identical or similar assets or liabilities in markets that are not active" (IFRS 13.82). The analysis shows that for companies in the research sample, the assessment of the fair value of PPE is carried out by certified external appraisers, mostly by appraisers that work as bank appraisers.

\section{Conclusion}

The revaluation model represents one of two accounting models for subsequent measurement of PPE according to national and international accounting standards. As the research results show, the revaluation model is applied by a very small number of companies (only 44 or 8.8 percent of the companies in the research sample, which consists of 500 companies), while the other companies apply the cost model. The share of companies from our sample that use the revaluation model for subsequent measurement of property, plant, and equipment is consistent with the sample size in other research that has analyzed the application of the revaluation model for subsequent measurement of property, plant, and equipment: for example, 9 percent in the research conducted by Aljinović Barać and Šodan (2011), 2 percent for UK companies and 7 percent for Australian companies in the research conducted by Cairns et al. (2011), 8.38 percent in the research conducted by Cheng and Lin (2009), and 8 percent in the research of Barlev, Fried, Haddad, and Livnat (2007). Most of the companies that apply the revaluation model apply this model for subsequent measurement of land, and a smaller number of companies apply the revaluation model for subsequent measurement of all other PPE. The companies in our sample usually conduct a revaluation every five years. The companies mostly apply the cost model as opposed to the revaluation model for subsequent measurement of property, plant, and equipment because of the high costs of fair value determination, non-existence 
of an active market for property, plant, and equipment, unreliable assessment of fair value, higher costs of depreciation, and other reasons.

The conducted analysis of disclosed information regarding the revaluation and fair value determination shows that most companies in Croatia disclose poor-quality notes to the financial statements that do not contain all the information required by the accounting standards. This leads us to the conclusion that managers of Croatian companies do not want to publish information on determining the fair value of their assets, thereby affecting the relevance and reliability of their financial statements. Accordingly, the information asymmetry between internal and external users of financial statements deepens in such circumstances.

The conducted analysis of the impact of the size of the company and the company's profitability on the level of disclosed information in the notes to the financial statements shows a positive correlation, but this correlation is not statistically significant. If the company applies the revaluation model for subsequent measurement of PPE, these assets are carried at a revalued amount, which is the fair value at the date of revaluation. The fair value of PPE is mostly based on level 2 inputs, which is expected, because an active market for non-financial assets does not exist in Croatia. Finally, external appraisers are often involved in the assessment of the fair value of PPE.

Taking into consideration that research on the application of the revaluation model in Croatian companies is rare, the results of this study could be useful and interesting to the academic community, master's students in accounting, as well as to practitioners and various stakeholders involved or interacting with others in the measurement of company assets at fair value.

The main limitation of this research is related to the size of the research sample. Due to this limitation, the conclusions of the research are based on a small amount of data (companies) about the use of the revaluation model and they cannot be generalized to the whole population (all companies in Croatia). Furthermore, the research was limited to companies from the service (utilities), production, and 
tourism sectors and to applying the revaluation model for subsequent measurement of PPE. Further research could include a wider population of companies that are required to apply IAS 16 or CFRS 6. Moreover, there is a possibility to expand the research on the whole group of long-lived operating assets. The other direction of future research could be focused on the factors (internal and external) that influence the manager's choice of accounting policy.

\section{Literature}

Aboody, D., Barth, M. E., \& Kasznik, R. (1999). Revaluations of fixed assets and future firm performance: Evidence from the UK. Journal of Accounting and Economics, 26(1-3), 149-178.

doi: https://doi.org/10.1016/S0165-4101(98)00040-8

Aljifri, K. (2008). Annual report disclosure in a developing country: The case of the UAE. Advances in Accounting, 24(1), 93-100.

doi: https://doi.org/10.1016/j.adiac.2008.05.001

Aljinović Barać, Ž., \& Šodan, S. (2011). Motives for assets revaluation policy choice in Croatia. Croatian Operational Research Review, 2(1), 60-70. Retrieved from: https://hrcak.srce.hr/96618

Bae, J., Lee, J., \& Kim, E. (2019). Does fixed asset revaluation build trust between management and investors? Sustainability, 11(13), 3700.

doi: https://doi.org/10.3390/su11133700

Ball, R. (2006). International Financial Reporting Standards (IFRS): Pros and cons for investors. Accounting and Business Research, 36(sup1), 5-27.

doi: https://doi.org/10.1080/00014788.2006.9730040

Barlev, B., Fried, D., Haddad, J. R., \& Livnat, J. (2007). Reevaluation of revaluations: A cross-country examination of the motives and effect on future performance. Journal of Business Finance and Accounting, 34(7-8), 1025-1050. doi: https://doi.org/10.1111/j.1468-5957.2007.02019.x 
Beatty, A., \& Liao, S. (2014). Financial accounting in the banking industry: A review of the empirical literature. Journal of Accounting and Economics, 58(2-3), 339-383. doi: https://doi.org/10.1016/j.jacceco.2014.08.009

Botelho, R., Azevedo, G., Costa, A., \& Oliveira, J. (2015). Property, plant and equipment disclosure requirements and firm characteristics: The Portuguese Accounting Standardization System. International Journal of Academic Research in Accounting, Finance and Management Sciences, 5(1), 58-71.

doi: http://dx.doi.org/10.6007/IJARAFMS/v5-i1/1459

Cairns, D., Massoudi, D., Taplin, R., \& Tarca, A. (2011). IFRS fair value measurement and accounting policy choice in the United Kingdom and Australia. British Accounting Review, 43(1), 1-21.

doi: https://doi.org/10.1016/j.bar.2010.10.003

Chainirun, P., \& Narktabtee, K. (2009). The evidence of management motivation to revalue property plant and equipment in Thailand. NIDA Business Journal, 5, 134-155. Retrieved from:

http://mba.nida.ac.th/en/books/read/cd847870-ffc8-11e6-ac1e-3127dc344227

Cheng, C. S. A., \& Lin, S. W. J. (2009). When do firms revalue their assets upwards? Evidence from the UK. International Journal of Accounting and Information Management, 17(2), 166-188. doi: https://doi.org/10.1108/18347640911001212

Choi, T. H., Pae, J., Park, S., \& Song, Y. (2013). Assets revaluations: Motives and choice of items to revalue. Asia-Pacific Journal of Accounting and Economics, 20(2), 144-171. doi: https://doi.org/10.1080/16081625.2012.719858

Christensen, H. B., \& Nikolaev, V. V. (2013). Does fair value accounting for nonfinancial assets pass the market test? Review of Accounting Studies, 18(3), 734-775. doi: https://doi.org/10.1007/s11142-013-9232-0

Cotter, J., \& Richardson, S. (2002). Reliability of assets revaluations: The impact of appraiser independence. Review of Accounting Studies, 7(4), 435-457. doi: https://doi.org/10.1023/A:1020763612369 
Croatian Bureau of Statistics. (2020). Annual average house price indices. Retrieved from:

https://www.dzs.hr/Hrv/publication/FirstRelease/results.asp?pString=Indeksi\%20 cijena\%20st\&pSearchString=\%Indeksi\%20cijena\%20st $\%$

Croatian Financial Reporting Standards (Odluka o objavljivanju Hrvatskih standarda financijskog izvještavanja). (2015). Official Gazette, 86/2015, 105/2020.

Fargher, N., \& Zhang, J. Z. (2014). Changes in the measurement of fair value: Implications for accounting earnings. Accounting Forum, 38(3), 184-199.

doi: https://doi.org/10.1016/j.accfor.2014.06.002

Gastón, S. C., García, C. F., Jarne, J. I. J., \& Gadea, J. A. L. (2010). IFRS adoption in Spain and the United Kingdom: Effects on accounting numbers and relevance. Advances in Accounting, 26(2), 304-313. doi: https://doi.org/10.1016/j.adiac.2010.08.003

Gaynor, L. M., McDaniel, L., \& Yohn, T. L. (2011). Fair value accounting for liabilities: The role of disclosures in unraveling the counterintuitive income statement effect from credit risk changes. Accounting, Organizations and Society, 36(3), 125-134. doi: https://doi.org/10.1016/j.aos.2011.03.004

Greenberg, M. D., Helland, E., Clancy, N., \& Dertouzos, J. N. (2013). Fair value accounting, historical cost accounting, and systemic risk: Policy issues and options for strengthening valuation and reducing risk. Cambridge: RAND Corporation.

Gulin, D. (2021). Značaj umanjenja imovine zbog COVID-19 u financijskim izvještajima za 2020. godinu. Računovodstvo i financije, 67(1), 9-12.

Gulin, D., \& Hladika, M. (2016). Challenges in applying the fair value accounting during financial crisis. MultiScience - XXX. microCAD International Multidisciplinary Scientific Conference, University of Miskolc, Hungary. doi: https:// doi.org/10.26649/musci.2016.138

Gulin, D., Hladika, M., \& Bernat, I. (2019). Analysis of profitability of hotel industry in Croatia. In K. S. Soliman (Ed.), Proceedings of the 34th International Business Information Management Association (IBIMA) Conference (pp. $5186-$ 5194). 
Gulin, D., Hladika, M., \& Mićin, M. (2017). Application of the fair value concept in function of achievement the objectives of financial statement users. In M. H. Bilgin, H. Danis, E. Demir, \& U. Can (Eds.), Country Experiences in Economic Development, Management and Entrepreneurship: Proceedings of the 17th Eurasia Business and Economics Society Conference, Eurasian Studies in Business and Economics, Vol. 5 (pp. 553-570).

Herrmann, D., Saudagaran, S. M., \& Thomas, W. B. (2006). The quality of fair value measures for property, plant and equipment. Accounting Forum, 30(1), 4359. doi: https://doi.org/10.1016/j.accfor.2005.09.001

Hu, F., Percy, M., \& Yao, D. (2015). Asset revaluations and earnings management: Evidence from Australian companies. Corporate Ownership \& Control, 13(1), 1287-1296. doi: https://doi.org/10.22495/cocv13i1c11p1

IASPlus. (2013). IFRS 13 Fair value measurement - Technical summary. Retrieved from: https://www.iasplus.com/en/standards/ifrs/ifrs13

IASPlus. (2015). IAS 16 Property, plant and equipment - Technical summary. Retrieved from: https://www.iasplus.com/en/standards/ias/ias16

Laux, C. (2012). Financial instruments, financial reporting, and financial stability. Accounting and Business Research, 42(3), 239-260.

doi: https://doi.org/10.1080/00014788.2012.681857

Lopes, A. B., \& Walker, M. (2012). Asset revaluations, future firm performance and firm-level corporate governance arrangements: New evidence from Brazil. The British Accounting Review, 44(2), 53-67.

doi: https://doi.org/10.1016/j.bar.2012.03.007

Lopes, P. T., \& Rodrigues, L. L. (2007). Accounting for financial instruments: An analysis of the determinants of disclosure in the Portuguese stock exchange. The International Journal of Accounting, 42(1), 25-56.

doi: https://doi.org/10.1016/j.intacc.2006.12.002 
Majercakova, D., \& Skoda, M. (2015). Fair value in financial statements after financial crisis. Journal of Applied Accounting Research, 16(3), 312-332. doi: https://doi.org/10.1108/JAAR-07-2014-0069

McDonough, R., Panaretou, A., \& Shakespeare, C. (2020). Fair value accounting: Current practice and perspectives for future research. Journal of Business Finance \& Accounting, 47(3-4), 303-332. doi: https://doi.org/10.1111/jbfa.12447

Missonier-Piera, F. (2007). Motives for fixed-asset revaluation: An empirical analysis with Swiss data. The International Journal of Accounting, 42(2), 186-205. doi: https://doi.org/10.1016/j.intacc.2007.04.006

Morais, A. I., \& Fialho, A. (2008). Do harmonised accounting standards lead to harmonised accounting practices? An empirical study of IAS 39 measurement requirements in some European Union countries. Australian Accounting Review, 18(3), 224-236. doi: https://doi.org/10.1111/j.1835-2561.2008.0027.x

Müller, M. A., Riedl, E. J., \& Sellhorn, T. (2015). Recognition versus disclosure of fair values. The Accounting Review, 90(6), 2411-2447.

doi: https://doi.org/10.2308/accr-51044

Nobes, C., \& Stadler, C. (2013). How arbitrary are international accounting classifications? Lessons from centuries of classifying in many disciplines, and experiments with IFRS data. Accounting, Organizations and Society, 38(8), 573595. doi: https://doi.org/10.1016/j.aos.2013.10.001

Oliveira, L., Rodrigues, L. L., \& Craig, R. (2006). Firm-specific determinants of intangibles reporting: Evidence from the Portuguese stock market. Journal of Human Resource Costing \& Accounting, 10(1), 11-33.

doi: https://doi.org/10.1108/14013380610672657

Palea, V. (2014). Fair value accounting and its usefulness to financial statement users. Journal of Financial Reporting and Accounting, 12(2), 102-116. doi: https://doi.org/10.1108/JFRA-04-2013-0021 
Perčević, H., Hladika, M., \& Valenta, I. (2020). The analysis of the appliance of fair value concept in Croatian companies from real sector. In M. H. Bilgin, $\mathrm{H}$. Danis, \& E. Demir (Eds.), Proceedings of the 26th and 27th Eurasia Business and Economics Society Conferences (pp. 17-29).

Procházka, D. (2011). The role of fair value measurement in the recent financial crunch. Prague Economic Papers, 20(1), 71-88.

doi: https://doi.org/10.18267/j.pep.388

Rahman, M. T., \& Hossain, S. Z. (2020). Does fixed assets revaluation create avenues for financial numbers game? Evidence from a developing country. Journal of Asian Finance, Economics and Business, 7(9), 293-304.

doi: https://doi.org/10.13106/jafeb.2020.vol7.no9.293

Regulation (EC) No. 1606/2002 of the European Parliament and of the Council of 19 July 2002 on the application of international accounting standards. (2002). Official Journal of the European Communities, L 243. Retrieved from:

https://eur-lex.europa.eu/legal-content/EN/TXT/PDF/?uri=CELEX:32002R160 6\&from $=$ en

Ronen, J. (2008). To fair value or not to fair value: A broader perspective. Abacus, 44(2), 181-208. doi: https://doi.org/10.1111/j.1467-6281.2008.00257.x

Sellhorn, T., \& Stier, C. (2019). Fair value measurement for long-lived operating assets: Research evidence. European Accounting Review, 28(3), 573-603.

doi: https://doi.org/10.1080/09638180.2018.1511816

Seng, D., \& Su, J. (2011). Asset devaluations: The motivation behind management decisions evidence from New Zealand firms. International Journal of Business Strategy, 11(2), 67-76. Retrieved from: https://www.ashesi.org/wp-content/ uploads/2016/03/Country-Branding.pdf\#page $=71$

Song, C. J., Thomas, W. B., \& Yi, H. (2010). Value relevance of FAS no. 157 Fair value hierarchy information and the impact of corporate governance mechanisms. The Accounting Review, 85(4), 1375-1410.

doi: https://doi.org/10.2308/accr.2010.85.4.1375 
Song, Y., \& Pae, J. (2019). The impact of appraisal quality on the voluntary disclosure of asset revaluation. Asia-Pacific Journal of Financial Studies, 48(5), 615639. doi: https://doi.org/10.1111/ajfs.12275

Šodan, S. (2009). Primjena metode fer vrijednosti u vrednovanju dugotrajne nefinancijske imovine u Hrvatskoj. In B. Ramljak (Ed.), Računovodstveno izvještavanje u RH i harmonizacija sa zahtjevima EU (pp. 69-85).

Yao, D., Percy, M., Stewart, J., \& Hu, F. (2018). Determinants of discretionary fair value measurements: The case of level 3 assets in the banking sector. Accounting and Finance, 58(2), 561-597. doi: https://doi.org/10.1111/acfi.12225

Zakon o računovodstvu (Law on Accounting). (2015). Official Gazette, 78/2015, $134 / 2015,120 / 2016,116 / 2018,42 / 2020,47 / 2020$.

Zyla, M. L. (2013). Fair value measurement: Practical guidance and implementation. Hoboken, NJ: John Wiley \& Sons, Inc. 